\title{
PENGEMBANGAN MODEL KOMPENSASI BERBASIS KOMPETENSI DI UNIVERSITAS TERBUKA
}

\author{
Amalia Kusuma Wardini (amalia@mail.ut.ac.id) \\ Universitas Terbuka
}

\begin{abstract}
The transformation into stated-owned legal body (BHMN/BHP) makes quite a significant impact on UT management, since the autonomy is wider and consequently it brings bigger responsibilities and challenges. One of these challenges is adjusting compensation system which previously referred to Civil Servants System and currently has several weaknesses, such as externally less competitive salary level, very close gap between highest and lowest salary and minimal concern about performance. It leads to the need of designing new compensation system during UT-BHP transitional period (2008-2017). Competency based Pay $(\mathrm{CbP})$ which is rewarding the way people work, not just recognizing what they can be deliver, fits the academic world. In a learning organization, colleges and universities certainly qualify, the focus on competence and the importance of individual growth is tied explicitly to the organization's mission and value also consistent with the growing interest in life long learning. The acceptance of individual development and skill acquisition as the criteria for rewarding staff employees should be a natural in higher education. This compensation design is focused on academic staffs, which are lecturer, researcher, and managerial position. Base salary and allowances have several alternatives, and choice will be made based on UT-BHP financial condition and the suitability with UT-BHP human resources development strategy.
\end{abstract}

Keywords: competency based pay, model.

Dalam organisasi pemerintahan, sistem kompensasi mengacu pada Peraturan Pemerintah Nomor 66 Tahun 2005 tentang Daftar Daji Pokok Pegawai Negeri Sipil (PNS) diperbaharui dalam PP Nomor 9 Tahun 2007. Sedangkan dalam memberikan paket remunerasi lain seperti tunjangan primer, sekunder, tersier dan kondisi kekaryaan lain organisasi dapat mengembangkan sistem remunerasinya sebagaimana diatur dalam Undang-undang Nomor 13 Tahun 2003 tentang Ketenagakerjaan dan Penjelasan Perundang-undangan Ketenagakerjaan Tahun 2005. Berkaitan dengan rencana pengembangan Universitas Terbuka (UT) menjadi Badan Hukum Pendidikan (BHP) pada tahun 2008-2017 maka perubahan status UT tersebut membawa dampak yang cukup berarti dalam pengelolaan UT. Sebagai BHP, otonomi yang dimiliki menjadi lebih luas serta konsekuensi tanggung-jawab dan tantangan yang lebih besar pula. Salah satu tantangannya adalah menyesuaikan sistem kompensasi yang sebelumnya berpedoman pada peraturan PNS. Upaya yang sedang dilakukan oleh UT saat ini adalah pengembangan sistem Kompensasi ber-basis Kinerja (KbK) yang lebih sesuai untuk diterapkan dalam organisasi yang berkembang. KbK diharapkan dapat menjadi alat transformasi Pengembangan Model Kompensasi berbasis Kompetensi (CbP) di masa mendatang. 
$\mathrm{CbP}$ dianggap model yang natural dan dapat diterima oleh komunitas akademis karena sifatnya yang menghargai individu berdasarkan pengembangan kapabilitas (Risher, 2006). Penerapan konsep CbP dalam institusi pendidikan memotivasi karyawan untuk senantiasa menambah keahlian dan keterampilan untuk mencapai kinerja dalam melaksanakan tugas. Karyawan diberikan kenaikan gaji berdasarkan pertambahan pengetahuan dan ketrampilan atau ketika mereka bisa menunjukkan tingkat kompetensi yang lebih tinggi daripada kapabilitasnya saat ini. Penilaian terhadap kompetensi karyawan dilakukan secara periodik, umumnya sekali setahun. Selain kenaikan gaji, penilaian kompetensi ini juga menjadi dasar dalam kenaikan jenjang karir. Kompetensi dalam konteks ini mengacu pada knowledge, skills, abilities, and learned behaviors. Kompetensi merupakan karakteristik keahlian yang mendasari keberhasilan atau kinerja yang dicapai seseorang. Kompetensi adalah spesifikasi perilaku-perilaku yang ditunjukkan mereka yang memiliki kinerja yang sempurna secara lebih konsisten dan lebih efektif dibandingkan dengan mereka yang memiliki kinerja dibawah rata-rata. Bila mengevaluasi kompetensi yang dimiliki oleh seseorang maka diharapkan bisa memprediksi kinerja orang tersebut (Cyra \& Benjamin,1998). Hal ini mengandung definisi yang berbeda namun fokusnya adalah pada kapabilitas individu dalam melaksanakan tugas. Model $\mathrm{CbP}$ ini mengandung arti bahwa semakin kompeten karyawan, semakin besar harapan institusi dan semakin besar pula kompensasi yang mereka terima.

Dilatarbelakangi oleh rencana restrukturisasi organisasi UT-BHP, maka permasalahan dalam artikel ini adalah "Bagaimana pengembangan model Kompensasi berbasis Kompetensi atau Competency based Pay (CbP) di Universitas Terbuka". Sedangkan tujuan dilakukannya kajian ini adalah untuk mengindentifikasi aspek kompensasi dan aspek kompetensi sebagai pengembangan model $\mathrm{CbP}$. Adapun alasan mengaitkan kompensasi dengan kompetensi adalah bahwa : 1) organisasi berkinerja tinggi memerlukan pegawai berkompetensi tinggi dan perlu memberi imbalan yang tinggi pula kepada mereka sesuai dengan tingkat kompetensinya dan kontribusinya pada keberhasilan bisnis, 2) memberi imbalan sesuai dengan tingkat kompetensi pegawai berarti menyampaikan pesan bahwa kompetensi itu penting. Kompensasi berkait dengan kompetensi dapat didefinisikan sebagai sebuah metode untuk memberikan imbalan dengan seluruhnya atau sebagian berpatokan pada tingkat kompetensi yang ditunjukkan oleh pegawai dalam menjalankan perannya (Armstrong \& Murlis, 2003).

Definisi ini mengandung tiga hal penting:

1. Kompensasi berkait dengan kompetensi tidak bersifat langsung. Berbeda dengan penguasaan tingkat ketrampilan, penguasaan tingkat kompetensi sulit diukur.

2. Pegawai bisa diberi imbalan dengan seluruhnya atau sebagian berpatokan pada tingkat kompetensinya. kompensasi berkait dengan kompetensi bukan berarti seluruhnya didasarkan pada kompetensi semata. Kompetensi bukanlah satu-satunya faktor dalam menentukan besar kecilnya kompensasi. Faktor lainnya adalah kinerja pegawai dan tekanan pasar tenaga kerja.

3. Kompensasi berkait dengan kompetensi berkaitan dengan perilaku yang menghasilkan kinerja, bukan perilaku itu sendiri. Kompensasi berkait dengan kompetensi bukanlah mengenai penguasaan kompetensi, melainkan mengenai efektivitas penggunaan kompetensi untuk menghasilkan nilai tambah. Kompetensi tidak bisa diukur secara tepat dengan hanya mengamati perilaku pegawai. Kompetensi hanya bisa diukur dengan mempertimbangkan dampak perilaku pegawai terhadap kinerja di tempat kerja. 
Menurut Simpson (2006) beberapa faktor yang harus dipertimbangkan sebelum menerapkan $\mathrm{CbP}$ adalah sebagai berikut.

1. Sistem penilaian kinerja karyawan telah berjalan dengan baik

2. Manajer dan supervisor telah diberikan pelatihan bagaimana melaksanakan penilaian kompetensi

3. Karyawan telah memahami dengan jelas kompetensi yang dibutuhkan organisasi dan bagaimana mereka menunjukkan kompetensi mereka jika dilakukan penilaian

4. Semua karyawan harus memiliki komitmen penuh

5. Sistem ini diberlakukan secara adil dan merata terhadap seluruh karyawan

Kebanyakan sistem $\mathrm{CbP}$ ditentukan oleh indikator kinerja, namun pada prinsipnya

kompetensi harus menunjukkan peningkatan dan dapat dikuantifikasikan oleh senior manajer melalui wawancara, survei dan analisa jabatan. Berikut ini merupakan kompetensi yang relevan.

a. Kompetensi inti dapat diterapkan pada seluruh pekerjaan dalam organisasi dan mencerminkan nilai inti organisasi

b. Ketrampilan teknis dan keahlian yang penting untuk melaksanakan tugas

c. Kompetensi berhubungan dengan kategori jabatan yang spesifik, misalnya kriteria kepemimpinan untuk senior manajer.

d. Kompetensi yang memberikan kontribusi terhadap peran karyawan dalam organisasi termasuk: komunikasi, teamwork dan motivasi, coaching, pengetahuan dan pengalaman, sikap melayani, menjalin hubungan, analisis dan investigasi, inisiatif dan pemecahan masalah, perencanaan dan pengorganisasian sumber daya serta pengambilan keputusan dan hasil akhir.

Pejabat berwenang harus mempertimbangkan hal-hal berikut ini sebelum menentukan kerangka kompetensi.

a. Mendorong kerjasama, rasa memiliki dan komitmen dari seluruh karyawan dengan melibatkan mereka dalam proses

b. Memastikan bahwa kerangka kompetensi relevan baik bagi kinerja individu maupun kinerja organisasi

c. Menyertakan analisis pekerjaan yang relevan dan terencana untuk mengantisipasi perubahan yang mengakibatkan cara kerja karyawan

d. Memastikan bahwa data yang dikumpulkan objektif dan sesuai dengan praktek

e. Memastikan bahwa kompetensi dan kinerja memiliki hubungan yang jelas

f. Memastikan bahwa bahasa yang digunakan dalam kerangka CbP tidak menimbulkan kesalahpahaman dan telah melalui uji sebelum diimplementasikan.

Menurut Long (1998), CbP merupakan sistem penggajian yang didasarkan atas nilai total keahlian dan kompetensi yang dimiliki oleh masing-masing tenaga kerja. Metode ini dilaksanakan dengan melibatkan kapasitas individu dan bukan pada karakteristik pekerjaannya. Terdapat tiga keuntungan penting dari sistem $\mathrm{CbP}$ yang berkaitan dengan pengembangan keahlian dan fleksibilitas yaitu:

a. Insentif bagi karyawan yang mempelajari berbagai keahlian sehingga memudahkan rotasi pekerjaan yang berbeda-beda sesuai kebutuhan.

b. Fleksibilitas menguntungkan organisasi dimana terdapat unit-unit yang beban kerjanya naik turun.

c. $\mathrm{CbP}$ tidak membutuhkan job description sehingga memudahkan organisasi yang berkembang cepat 
d. Kompetensi yang dimiliki karyawan lebih beragam sehingga pekerjaan menjadi lebih umum, workforce yang digunakan menjadi lebih efisien dan organisasi bisa beroperasi dengan sumber daya manusia yang lebih sedikit.

e. Sistem $\mathrm{CbP}$ mendukung praktek manajemen high involvement dimana karyawan dengan beragam pengetahuan dapat terlibat secara efektif dalam proses pengambilan keputusan, membuat penilaian dan bertindak cepat.

Adapun kendala yang mungkin terjadi dalam sistem $\mathrm{CbP}$ adalah:

a. Gaji yang terlalu tinggi dibandingkan gaji rata-rata dalam industri menyebabkan karyawan yang telah mencapai gaji tertinggi kehilangan motivasi belajar untuk memperbaharui keahliannya.

b. Sistem $\mathrm{CbP}$ membutuhkan biaya tinggi untuk kebutuhan pelatihan

c. Sistem $\mathrm{CbP}$ agak menyimpang dari kesetaraan gaji yang seharusnya diperoleh karyawan berdasarkan pekerjaannya bukan kapabilitasnya. Namun pengecualian berlaku umum untuk faktor tertentu seperti tingkat keahlian dan pengalaman yang relevan (Long, 1998).

Metode yang digunakan dalam penelitian ini adalah metode kualitatif dengan pendekatan model normatif. Berkaitan dengan rencana pengembangan sistem kompensasi di UT maka pengembangan model $\mathrm{CbP}$ ini bermaksud menyediakan jawaban terbaik bagi persoalan dan memberi rekomendasi tindakan yang perlu diambil (Simarmata, 1983) berkaitan dengan masalah pengembangan sistem CbP di UT. Sedangkan dari proses penelitiannya menggunakan model hipotetik karena dibuat hanya sampai pada terbentuknya pengembangan model, sedangkan taraf pengujiannya dibutuhkan penelitian lebih lanjut. Pengembangan model $\mathrm{CbP}$ ini baru terbatas pada jabatan staf akademik yaitu pengajar, peneliti, dan manajerial akademis.

Faktor-faktor yang diteliti dalam penelitian ini adalah pertama, struktur penggajian berdasarkan PP Nomor 66 Tahun 2005 diperbaharui dalam PP Nomor 9 Tahun 2007; dan PP Nomor 3 Tahun 2006; kedua, kompetensi pegawai meliputi berbagai jenis keahlian yang telah dan harus dimiliki pegawai. Unit standar kompetensi yang digunakan adalah sesuai dengan standar kompetensi industri pendidikan dan terbatas pada jabatan akademis. Oleh karena itu, standar kompetensi yang digunakan dalam penelitian ini menggunakan standar kompetensi jabatan dosen di UT; ketiga, kebijakan UT meliputi struktur penggajian dan segala sesuatu yang berkaitan dengan kebijakan kompensasi UT sesuai dengan SK Rektor; keempat, model CbP yang dikembangkan meliputi klasifikasi jabatan, struktur penggajian, dan syarat kompetensi yang harus dipenuhi. Untuk pengambilan data, instrumen yang digunakan dalam penelitian ini adalah in-depth interview dengan karyawan dan pejabat yang terkait dengan pengembangan sistem kompensasi di UT.

\section{HASIL DAN PEMBAHASAN}

\section{Standar Kompetensi Jabatan Staf Akademik UT}

Restrukturisasi organisasi yang terus berlangsung, perkembangan iptek yang sangat cepat, persaingan dalam industri yang sedemikian ketat menghasilkan anggapan baru bahwa untuk mengatasi semua tantangan dibutuhkan individu yang memiliki beragam keahlian (multi skilling) yang mendukung pekerjaannya. Sehingga dengan beragam keahlian diharapkan karyawan benar-benar kompeten dalam pekerjaannya. Berkaitan dengan rencana induk pengembangan sumber daya manusia (SDM) UT yang berisi target pengembangan, strategi pencapaian dan waktu pencapaian, maka pada tahap awal UT telah mengembangkan Daftar Kompetensi Staf Edukatif yang seharusnya ada pada perguruan tinggi jarak jauh (PTJJ) dan disusun sesuai dengan standar internasional. 
Mempertimbangkan banyaknya profesi dan keahlian yang melekat pada staf UT yang terdiri dari staf akademik, staf administrasi dan teknisi, maka dalam kajian ini hanya akan dibahas mengenai standar kompetensi jabatan staf akademik. Staf akademik UT sebagai penyelenggara PTJJ dituntut untuk memiliki 89 jenis kompetensi yang dikelompokkan kedalam 25 sub bidang kompetensi dan 9 bidang kompetensi sebagai berikut.

Tabel 1. Jenis Bidang Pengembangan Kompetensi

\begin{tabular}{lcc}
\hline Bidang & Sub bidang & Kompetensi \\
\hline Pengembangan program dan kurikulum & 4 & 13 \\
Pengembangan bahan ajar & 10 & 37 \\
Bantuan belajar & 3 & 12 \\
Evaluasi hasil belajar & 2 & 9 \\
Keperpustakaan & 1 & 2 \\
Penelitian & 1 & 3 \\
Teknologi Informasi dan Komunikasi & 1 & 2 \\
Administrasi akademik & 2 & 8 \\
Hubungan masyarakat & 1 & 3 \\
\hline Total & 25 & 89 \\
\hline
\end{tabular}

Sumber: UT (2006)

Tabel 2. Daftar Kompetensi Staf Akademik UT

\begin{tabular}{l}
\hline \multicolumn{1}{c}{ Kompetensi } \\
\hline Bidang Pengembangan Program dan Kurikulum \\
\hline Pengembang kurikulum/ Program studi \\
a. Mampu mengembangkan naskah akademik \\
b. Mampu menyusun struktur kurikulum \\
c. Mampu mengembangkan rancangan mata kuliah/RMK (GBPP+Analisis Kompetensi) \\
d. Mampu mengembangkan dan meng-update profil mata kuliah \\
e. Berkemampuan mengevaluasi mata kuliah \\
Desain instruksional \\
a. Menguasai teori dan strategi pembelajaran \\
b. Menguasai teori pendidikan secara umum \\
c. Menguasai pemanfaatan media pembelajaran \\
Evaluasi program \\
a. Menguasai teori pendidikan secara umum \\
b. Menguasai teori evaluasi program \\
Pengelola pengembangan program \\
a. Mempunyai keterampilan kepemimpinan \\
b. Mampu merencanakan, mengorganisasikan, melaksanakan, mengendalikan, dan mengevaluasi pekerjaan \\
c. Mem MDM \\
\hline Bidang Pengembangan Bahan Ajar \\
\hline Penulis bahan ajar cetak \\
a. Menguasai materi \\
b. Menguasai teknik penulisan bahan ajar cetak \\
c. Mampu menulis bahan ajar cetak
\end{tabular}


Editor dan Penelaah

a. Menguasai materi

b. Menguasai teknik penulisan bahan ajar cetak

c. Menguasai teknik mengedit/menelaah bahan ajar cetak

d. Menguasai teknik penelaahan bahan ajar non cetak

e. Mampu mengedit/menelaah bahan ajar cetak

f. Mampu mengedit/menelaah bahan ajar non cetak

Penulis bahan ajar audio/radio
a. Menguasai materi
b. Mampu mengembangkan GBPM
c. Menguasai teknik penulisan audio/radio
d. Mampu menulis naskah audio/radio

Penulis bahan ajar video
a. Menguasai materi
b. Mampu mengembangkan GBPM
c. Menguasai teknik penulisan video
d. Mampu menulis naskah video

Penulis bahan ajar berbantuan komputer (CAl)
a. Menguasai materi
b. Mampu mengembangkan GBP CAI
c. Mampu menulis naskah CAI
d. Menguasai teknik penulisan bahan ajar berbantuan komputer (CAI)
e. Menguasai perangkat lunak pengembangan CAI
f. Mampu menulis naskah dalam bahasa komputer

Penulis bahan ajar Web Base
a. Menguasai materi
b. Menguasai teknik penulisan Web Base
c. Mampu menulis naskah dalam Web Base

Instruktur praktikum
a. Menguasai materi praktikum
b. Menguasai teknik praktikum (alat dan bahan)
c. Mampu menulis materi praktikum

Ahli desain grafis
a. Menguasai ilmu desain grafis
b. Memiliki ketrampilan desain grafis
c. Mampu membuat desain grafis

Media publisher

a. Menguasai ilmu media publisher

b. Memiliki ketrampilan media publisher

Pengelola pengembangan bahan ajar cetak dan non cetak

a. Mempunyai keterampilan kepemimpinan

b. Mampu merencanakan, mengorganisasikan, melaksanakan, mengendalikan, dan mengevaluasi pekerjaan dan SDM

c. Memiliki wawasan dan pengetahuan tentang pengembangan bahan ajar cetak dan non cetak Bidang Bantuan Belajar

Tutor/Fasilitator
a. Menguasai materi
b. Menguasai model-model tutorial dan instruksional
c. Menguasai keterampilan tutorial dan instruksional
d. Memiliki kemampuan mengevaluasi proses tutorial dan instruksional
e. Mampu melakukan tutorial 


\section{Kompetensi}

Pembimbing akademik/Konseling

a. Menguasai teknik konseling

b. Memahami sistem administrasi akademik

c. Menguasai berbagai sistem belajar

d. Mampu melakukan bimbingan akademik/konseling

Pengelola bantuan belajar

a. Mempunyai keterampilan kepemimpinan

b. Mampu merencanakan, mengorganisasikan, melaksanakan, mengendalikan, dan mengevaluasi pekerjaan dan SDM

c. Memiliki wawasan dan pengetahuan tentang bantuan belajar

Bidang Evaluasi Hasil Belajar

Penulis soal

a. Menguasai materi

b. Memiliki keterampilan menulis soal

c. Memiliki pengetahuan tentang evaluasi hasil belajar

d. Mampu menulis kisi-kisi dan indikator soal ujian

e. Mampu menulis naskah soal ujian

f. Mampu menelaah naskah soal ujian

g. Mampu merakit naskah soal ujian

Pengelola evaluasi hasil belajar

a. Mempunyai keterampilan kepemimpinan

b. Mampu merencanakan, mengorganisasikan, melaksanakan, mengendalikan, dan mengevaluasi pekerjaan dan SDM

c. Memiliki wawasan dan pengetahuan tentang evaluasi hasil belajar

Bidang Kepustakaan

Pustakawan

a. Menguasai ilmu perpustakaan

b. Memiliki ketrampilan mengelola perpustakaan

Bidang Penelitian

Peneliti

a. Menguasai metodologi penelitian

b. Menguasai materi

c. Menguasai PJJ

d. Mampu melaksanakan penelitian keilmuan

e. Mampu melaksanakan penelitian PJJ

Penulis karya ilmiah untuk seminar

a. Mampu menulis karya ilmiah bertaraf institusional

b. Mampu menulis karya ilmiah bertaraf nasional

c. Mampu menulis karya ilmiah bertaraf internasional

Penulis karya ilmiah untuk jurnal

a. Mampu menulis karya ilmiah bertaraf institusional

b. Mampu menulis karya ilmiah bertaraf nasional terakreditasi

c. Mampu menulis karya ilmiah bertaraf nasional tidak terakreditasi

d. Mampu menulis karya ilmiah bertaraf internasional terakreditasi

e. Mampu menulis karya ilmiah bertaraf internasional tidak terakreditasi

Bidang Teknologi Informasi dan Komunikasi

Penulis karya ilmiah untuk seminar

a. Mampu menulis karya ilmiah bertaraf institusional

b. Mampu menulis karya ilmiah bertaraf nasional

c. Mampu menulis karya ilmiah bertaraf internasional 
Kompetensi

Ahli Teknologi Informasi dan Komunikasi

a. Menguasai desain dan pengembangan perangkat keras

b. Menguasai desain dan pengembangan perangkat lunak

\begin{tabular}{l}
\hline Bidang Administrasi Akademik \\
\hline Manajer administrasi akademik \\
a. Memiliki keterampilan manajerial \\
b. Memiliki pengetahuan PJJ \\
c. Memiliki keterampilan perencanaan anggaran \\
d. Memiliki keterampilan pemasaran \\
e. Memiliki keterampilan perencanaan strategik \\
Koordinator administrasi akademik \\
a. Memiliki keterampilan manajerial \\
b. Memiliki pengetahuan PJJ \\
c. Memiliki keterampilan pemasaran \\
\hline Bidang Hubungan Masyarakat \\
\hline Hubungan Masyarakat \\
a. Memiliki pengetahuan hubungan masyarakat \\
b. Memiliki pengetahuan PJJ \\
c. Memiliki keterampilan promosi dan pemasaran
\end{tabular}

Sumber: UT (2006)

\section{Pengembangan Model Kompensasi Berbasis Kompetensi di UT}

Berdasarkan Daftar Kompetensi Staf Akademik di UT selanjutnya dibuat sebuah Model Kompetensi. Suatu model kompetensi mengidentifikasi kompetensi-kompetensi yang diperlukan oleh masing-masing pekerjaan serta pengetahuan, ketrampilan, perilaku dan karakterisitik personal yang merupakan bagian dari masing-masing kompetensi tersebut (Noe, 2002).

Tabel 3 menunjukkan Model Kompetensi yang dikelompokkan berdasarkan jabatan fungsional dosen. Kolom pertama menunjukkan kompetensi teknis mulai dari tenaga pengajar hingga guru besar dengan beragam kompetensi yang dimiliki sebagaimana daftar kompetensi staf akademik diatas. Sedangkan kolom kedua menunjukkan tingkat kecakapan untuk masing-masing kompetensi jabatan dosen.

Dari model kompetensi diatas, kemudian akan diperoleh skor tiap individu pegawai yang dikelompokkan ke dalam grup berdasarkan jabatan fungsional dosen. Skor terkecil adalah 0 dan skor terbesar adalah 356 dari 4 kelompok jabatan fungsional sebagaimana dapat dilihat pada Tabel 4 .

Tabel 3. Model Kompetensi Menurut Jabatan Fungsional Dosen

\begin{tabular}{|c|c|}
\hline Technical cluster & Proficiency Ratings \\
\hline Tenaga Pengajar & 0 - Tidak mampu menyelesaikan tugas-tugas mendasar \\
\hline \multirow[t]{4}{*}{ hingga Guru Besar } & 1 - Memahami prinsip dasar, dapat menyelesaikan tugas dengan bantuan atau \\
\hline & $\begin{array}{l}2 \text { - Menyelesaikan tugas-tugas rutin dengan hasil yang dapat diandalkan; bekerja dengan } \\
\text { pengawasan yang minim. }\end{array}$ \\
\hline & $\begin{array}{l}3 \text { - Menyelesaikan tugas yang kompleks dan beragam ; dapat melatih dan mengajarkan } \\
\text { rekan kerja yang lain. }\end{array}$ \\
\hline & 4 - Ahli dibidangnya; dapat menjelaskan, mengajarkan dan membimbing rekan kerja lain. \\
\hline
\end{tabular}

Sumber: Noe (2002) 
Tabel 4. Penyekoran Kompetensi Menurut Jabatan Fungsional Dosen

\begin{tabular}{ccll}
\hline Grade & Skor Kompetensi & \multicolumn{1}{c}{ Kriteria Dasar Pegawai } & \multicolumn{1}{c}{ Jabatan Fungsional } \\
\hline 0 & $0-356$ & Pendidikan S1 tanpa Pengalaman & Tenaga Pengajar \\
1 & $0-356$ & Pendidikan S1/S2/S3 dengan pengalaman Kum 100-150 & Asisten Ahli III/a - III/b \\
2 & $0-356$ & Pendidikan S1/S2/S3 dengan pengalaman Kum 200-300 & Lektor III/c - III/d \\
3 & $0-356$ & Pendidikan S1/S2/S3 dengan pengalaman Kum 400-700 & Lektor Kepala IV/a - IV/c \\
4 & $0-356$ & Pendidikan S1/S2/S3 dengan pengalaman Kum 850-1050 & Guru Besar IV/d - IV/e \\
\hline
\end{tabular}

Sumber: Hasil modifikasi dari Petunjuk Pelaksanaan Keputusan Menteri Pendidikan Nasional No 074/ U/2000 tentang Penyempurnaan Tata Kerja Tim Penilai dan Tata Cara Penilaian Angka Kredit Jabatan Dosen Universitas Terbuka.

Metode yang dapat digunakan dalam merancang struktur gaji pada $\mathrm{CbP}$ yaitu: broadbanding dan job families. Sistem broad-banding dapat menggunakan market rate dan job evaluation. Posisi karyawan dalam suatu band area tergantung dari kompetensi teknis yang mereka miliki. Keunggulan dari sistem broad-band ini bahwa karyawan dapat mengembangkan karir secara horisontal berdasarkan pengalaman dan kompetensi mereka dan dalam kenaikan gaji tidak diperlukan adanya kenaikan jabatan atau promosi. Dalam sistem job families, struktur gaji ditentukan oleh pengelompokkan fungsi pekerjaan berdasarkan perbedaan tingkat tanggung jawab dan kompetensi. Keunggulan dari sistem ini bahwa peningkatan karir berdasarkan peningkatan kompetensi dan karyawan mendapat kejelasan seberapa jauh peningkatan mereka dalam job family (Local Government Employers-London, 2007).

Struktur penggajian dalam CbP ini meliputi gaji pokok dan gaji tambahan. Perancangan gaji pokok mengacu pada gaji pokok PNS dan mempunyai 2 (dua) alternatif, yaitu berdasarkan penetapan experiense raise dan penetapan skala gaji minimum-maksimum. Sementara gaji tambahan meliputi tunjangan tetap dan tunjangan variabel. Tunjangan tetap merupakan tunjangan yang diberikan berdasarkan kompetensi yang dibutuhkan untuk melaksanakan tugas sesuai jabatannya saat ini. Tunjangan tetap diberikan untuk keempat jalur jabatan staf akademik berdasarkan analisis kompetensi jabatan. Tunjangan variabel merupakan tunjangan yang diberikan kepada staf akademik berdasarkan kompetensi dan kinerja individu. Kompensasi untuk kompetensi individu diberikan dalam bentuk tunjangan kepakaran, sedangkan penghargaan terhadap kinerja diberikan sebagai insentif prestasi. Sistem penilaian individu ini perlu dilakukan dalam penelitian tersendiri. Dalam penelitian ini, sistem penilaian individu mengambil hasil uji coba penilaian kinerja yang dilakukan oleh Pusat Jaminan Kualitas UT, berupa Indeks Prestasi Kerja (IPK) yang nilainya kemudian menjadi komponen perhitungan insentif prestasi. Kompensasi untuk kompetensi individu selain tunjangan kepakaran adalah kenaikan gaji pokok tambahan, yang berkisar antara $1 \%$ hingga $6 \%$, nilai ini diasumsikan dari kenaikan tingkat inflasi yang terjadi pada tahun itu. Sedangkan prestasi kerja individual dikompensasikan dengan bonus tahunan yang diberikan setiap awal tahun setelah akhir periode penilaian kinerja tahun sebelumnya, yang besarnya variatif tergantung besarnya IPK dengan kisaran sebesar $100 \%$ hingga $400 \%$ dari gaji pokok.

Dalam menerapkan sistem $\mathrm{CbP}$ perlu dipertimbangkan adanya pengembangan program Competency based Assesment (CbA) dan Competency based Training (CbT) terlebih dahulu untuk mengukur kompetensi individu karyawan dimana pengakuan beragam kompetensi yang dimiliki karyawan diwujudkan dalam bentuk sertifikasi. Sertifikasi tersebut yang dijadikan dasar dalam menentukan tingkat gaji. CbA dilaksanakan terlebih dahulu untuk menilai sejauh mana kompetensi yang dimiliki oleh setiap individu karyawan. Proses penilaian dilakukan dengan bantuan assesor 
yang dibentuk organisasi. Karyawan yang dinilai kompeten akan memperoleh sertifikat yang berisi ragam unit standar kompetensi yang telah dikuasai dalam bentuk skor kompetensi. Skor kompetensi merupakan dasar dalam menentukan salah satu unsur gaji dalam $\mathrm{CbP}$ sebagaimana dilihat dalam Tabel 5.

Tabel 5. Struktur Penggajian (Competency based Pay)

\begin{tabular}{|l|l|}
\hline A. Gaji Pokok \\
\hline \begin{tabular}{|l|}
\hline B. Gaji Tambahan \\
\hline B.1. Tunjangan Tetap
\end{tabular} & $\begin{array}{l}\text { Asisten Ahli -s/d- Guru Besar } \\
\text { Analisis kompetensi jabatan }\end{array}$ \\
\hline B.2. Tunjangan Variabel : & Kompetensi dan Kinerja individu \\
\hline a. Tunjangan kepakaran & Score dari Competency based Assesment \\
\hline b. Insentif Prestasi & IPK dari Performance appraisal \\
\hline C. Kenaikan gaji & \\
\hline C.1. Tunjangan kepakaran & Kompetensi individu \\
\hline C.2. Bonus tahunan & Kinerja individu \\
\hline
\end{tabular}

Tahap selanjutnya adalah $\mathrm{CbT}$, yang dilaksanakan apabila karyawan yang dinilai ternyata belum kompeten. Karyawan disarankan untuk mengikuti ragam pelatihan untuk memenuhi jenis keahlian yang belum dikuasai. Dari hasil pelatihan diharapkan karyawan memiliki kompetensi sesuai jabatannya. Ada dua hal pokok yang mendasari pelaksanaan program CbT yaitu kompetensi individu karyawan dan standar kompetensi yang digunakan. Sedangkan pengawasan standarisasi mutu pelaksanaan $\mathrm{CbA}$ dan $\mathrm{CbT}$ dilakukan oleh lembaga khusus yang bersifat independen dalam hal ini Badan Nasional Sertifikasi Profesi (BNSP) yang bertugas menetapkan kebijakan standarisasi, sertifikasi profesi dan akreditasi terhadap lembaga sertifikasi profesi.

Model $\mathrm{CbP}$ yang dikembangkan dalam kajian ini merupakan model $\mathrm{CbP}$ berdasarkan standar jabatan staf akademik UT dan kebijakan UT saat ini tentang implementasi sistem manajemen kinerja. Sehingga dalam pengembangannya dihasilkan pendekatan sistem penggajian yang secara garis besar meliputi gaji pokok yang mengandung aspek tingkatan pendidikan, golongan kepangkatan dan pengalaman kerja serta gaji tambahan yang mengandung aspek kompetensi dan kinerja individu. Namun pilihan yang dijatuhkan akan mengacu pada kemampuan finansial UT dan kesesuaian dengan strategi pengembangan SDM.

Berdasarkan pembahasan diatas, secara teoritis, pengembangan model CbP di UT sesuai dengan teori kompensasi yang telah ada, yaitu bahwa model $\mathrm{CbP}$ merupakan sistem penggajian yang didasarkan atas nilai total keahlian dan kompetensi yang dimiliki masing-masing karyawan (Long, 1998) dan kompetensi bukanlah satu-satunya faktor dalam menentukan besar kecilnya kompensasi, faktor lainnya adalah kinerja pegawai dan tekanan pasar tenaga kerja (Armstrong \& Murlis, 2003).

\section{PENUTUP}

Restrukturisasi UT menjadi BHP pada tahun 2008 - 2017 harus dibarengi dengan restukturisasi sistem manajemen sumber daya manusia yang sebelumnya mengacu pada peraturan PNS, salah satunya adalah sistem kompensasi. Sistem kompensasi PNS memiliki beberapa kekurangan untuk diterapkan dalam struktur baru UT, untuk itu perlu dilakukan perancangan sistem kompensasi baru yang mengarah pada sistem manajemen kinerja yaitu Kompensasi berbasis Kinerja 
yang akan segera diimplementasikan. Dalam sistem kompensasi berbasis kinerja, aspek kinerja individu menjadi pertimbangan yang utama. Struktur gaji memperhitungkan IPK dengan tetap mengacu pada struktur gaji PNS. Dalam perkembangan selanjutnya sebagai organisasi BHP, UT dituntut untuk dapat mengelola aset sumber daya manusia dari berbagai kualifikasi semakin profesional. Model CbP diharapkan menjadi model yang paling tepat diterapkan dalam institusi pendidikan yang berkembang karena berfokus pada peningkatan kompetensi individu yang mengarah pada kinerja organisasi. Namun perancangan baru dibatasi untuk staf akademik UT, yaitu jabatan pengajar, peneliti, dan manajerial akademis. Model CbP ini memperhitungkan aspek kompetensi individu berdasarkan standar jabatan staf akademik selain aspek kinerja individu yang merupakan daya dorong kinerja organisasi. Sementara model kompetensi yang dikembangkan mengandung total skor kompetensi terendah 0 dan tertinggi 356 dari 89 jenis kompetensi yang harus dimiliki sesuai standar jabatan dosen UT dengan proficiency rating 0 hingga 4 . Sedangkan metode yang dapat digunakan dalam merancang struktur gaji $\mathrm{CbP}$ yaitu broad-banding atau job families dan penetapan gaji pokok dapat menggunakan dua alternatif, experience raise atau skala gaji minimummaksimum. Aspek kompetensi dalam struktur penggajian model $\mathrm{CbP}$ ini sendiri dapat terlihat dalam aspek tunjangan tetap dan aspek tunjangan kepakaran.

Pendekatan kompetensi sangat cocok diterapkan dalam institusi pendidikan tinggi karena disamping filosofi manajemennya menyangkut pertumbuhan individu dan pemberdayaan, sistem $\mathrm{CbP}$ juga memotivasi tenaga akademis untuk terus mengembangkan ilmu pengetahuan untuk mencapai tingkatan kompetensi tertentu. Namun perlu dikembangkan lebih lanjut standar kompetensi jabatan tidak hanya terbatas pada jabatan akademik tetapi juga jabatan teknisi dan administratif. Selain diperlukan pengujian construct validity terhadap masing-masing item dalam standar kompetensi jabatan yang akan dikembangkan, juga diperlukan penelitian lebih lanjut untuk menganalisis struktur penggajian model $\mathrm{CbP}$ dan pengelolaan sistem $\mathrm{CbP}$.

\section{REFERENSI}

Armstrong, M. \& Murlis, H. (2003). Reward management. Jakarta: Gramedia.

Cyra \& Benjamin, E.R. (1998) Compentency-based pay: A concept in evolution. Compensation \& Benefits Review 30 (September/Oktober 1998), 21-28.

Departemen Tenaga Kerja. (2005). Peraturan Perundang-undangan RI tentang Ketenagakerjaan Tahun 2005. Jakarta: Departemen Tenaga Kerja.

Local Government Employers (LGE), London. (2007). Competency-based pay. Diambil tanggal 17 Januari 2007 dari www.lge.gov.uk.

Long,J. (1998). Pengembangan Model RbK di PT. PAL. Diambil tanggal 21 Nopember 2006 dari www.damandiri.or.id.

Noe, R.A. (2002). Employee Training and Development. New York: McGraw Hill.

Risher, H. (2006). Competency-based pay: The emerging model for salary management. Phoenix Arizona: Fox Lawson \& Associates LLC. Diambil tanggal 21 Nopember 2006. www.foxlawson.com.

Sekretaris Negara. (2007). Peraturan Pemerintah Republik Indonesia Nomor 9 Tahun 2007 tentang Perubahan Kesembilan atas Peraturan Pemerintah Nomor 7 Tahun 1977 tentang Daftar Gaji Pokok Pegawai Negeri Sipil. Diambil dari www.pu.go.id/sekjen\%20hukum/pp/pp09-2007.pdf.

Simarmata. (1983). Dirujuk dalam Anywedhiastuty. Diambil tanggal 21 Agustus 2007 dari www.damandiri.or.id/file/anywedhiastutyunairbab2.pdf. 
Simpson, S. (2006). Competencies: The core of human resource management. HRSG. Diambil tanggal 21 Nopember 2006. www.hrsg.ca.

Universitas Terbuka. (2002). Petunjuk Pelaksanaan Keputusan Menteri Pendidikan Nasional Nomor 74/ Tahun 2000 tentang Penyempurnaan Tata Kerja Tim Penilai dan Tata Cara Penilaian Angka Kredit Jabatan Dosen Universitas Terbuka. Jakarta: Universitas Terbuka.

Universitas Terbuka. (2006) Laporan Analisis Pengembangan Staf Akademik UT. Jakarta: Universitas Terbuka. 